\title{
Effect of Sports Satisfaction on Aggression and Stress in Judokas and Swimmers
}

\author{
Özlem Keskin \\ Correspondence: Özlem Keskin, Kocaeli University, Faculty of Sports Sciences, Umuttepe Campus, Kocaeli/İzmit, \\ Turkey.
}

Received: April 2, 2018

doi:10.11114/jets.v6i6.3142
Accepted: April 15, 2018

Online Published: April 17, 2018

URL: https://doi.org/10.11114/jets.v6i6.3142

\begin{abstract}
Entirely 60 athletes (39 judokas and 21 swimmers) participated in this study that was performed in 2 different branches (contact and contactless). The purpose of this paper was to determine the effect of sports satisfaction on aggression level and stress. Three different scales as the stress scale, aggression scale, and sports satisfaction scale were used to collect the data. T-test, one way ANOVA test, regression and correlation tests were used in independent groups to analyze the data obtained from these scales. SPSS 24.00 packaged software analyzed the data. It is seen when an evaluation based on the branches are actualized that point averages of sports satisfaction of both the judokas and swimmers are at a good level. While there is no significant difference in terms of the branch, gender, and education, there are significant differences $(p<0,01)$ in terms of the age group variable at the same time. With reference to our other finding, there is a negative relationship between the sports satisfaction and stress $(r=-, 320, p<0.01)$. As the sports satisfaction increases, stress level decreases at the same time. There is seen a negative significant relationship between the age group and aggression levels $(\mathrm{r}=-, 374, \mathrm{p}<0,01)$. As the age decreases, the aggression level increases.
\end{abstract}

Keywords: sports satisfaction, aggression, stress, judo, swimming

\section{Introducation}

Sportive performance is defined as motoric and psycho-motoric abilities that are revealed by the best opportunities to achieve a sportive goal. Feeling of excitement and discharge that sports provide places it to a privileged position (Kirtepe et al., 2017). Sports is a socializer, competitive, solidarist, cultural fact that improves soul and physics. Besides sports provide a person with occupation by improving his/her abilities and transform his/her natural environment to human environment in line with the principles with tools or without tools (Şirin et al., 2016).

Sports has started to function as a remarkable educational appliance in the solution of social problems by extending the point of interest to meet the different expectations of individuals. With reference to Fişek (1980), sports prepares a proper competition environment for the person to control the aggressive instinct that is in the nature of the beast and also the sports eases individual to commune with the society. Besides, sports provides physical, psychological and social benefits and includes the activities that guarantee the mental and physical health of the people (Göksel et al., 2017).

All in all, sports is accepted as a tool to form friendships between people and countries all over the world. It is mentioned when the sports is defined that it removes the aggression and lightens the burst of anger (Özdemir and Abakay, 2017).

Sport is a mean that creates an opportunity for improvement of people and contributes to the whole life of them. Without noticing the age, sports that systematically played with scientific basis plays a crucial role for the person to be healthy, happy and successful for the life (Göksel et al., 2017)

Athletes are accepted as the people who make sports a business and complete physical, psychological social adaptation processes required for the high performance by heavy and tiresome training for years. In work environment, they use not only the physical structure but also feelings and thoughts. Accordingly, the athlete is affected by sports activities that are a business for him. Moreover, he/she develops an attitude. The attitudes that are developed as pleasure and displeasure may create positive or negative effects on the athlete (Şirin et al., 2016). 
When it is considered that the athlete is in sports with not only the physical existence but also the thoughts, feelings, and judgments; the satisfaction in sports can be explained as the attitude and expectations of the athlete toward his/her own branch (Özmutlu, 2011). Sports satisfaction is an inseparable part of attending to sports and rejoicing in playing sports as well. Athletes seek for other sources for success and pleasure in case of lack of the satisfaction (Sirin et al., 2016). It is mentioned that the satisfaction level of athlete by attending to the sports has a significant role to be perceived the performance. Satisfaction level is an indicator of feeling and thoughts of a athlete about his/her team and environment (Özdevecioğlu and Yalçın, 2010).

Sports competition is one of most intense occasions where stress is felt quite intensely (Eraslan, 2017). Stress during sports, as in anything else in life, may be acute, episodic or chronic. For the most part in sports, it is episodic, whether during a competitive match between friends, or a championship game. While acute stress may actually act as a challenge, if not harnessed, it can evolve to not only an episodic stressor that can affect one in the long term but can also hamper one's play (Bali, 2015). Stress has a specific structure peculiar to individuals; it comes into existence in each second of the life cycle when possible but not clear when to occur. It is not true to say that it only occurs in work life or under difficult professional conditions. Managing stress factor-oriented situations and feelings rightly will be motivational acquirements of stress (Demir et al., 2017). Stress (uneasiness) has become a remarkable part of the modern life (Eskin et al., 2013). It emerges a fact that is felt by everyone in almost every environment (Örücü et al., 2011).

Performance always needs to increase for athlete to be and progress in competition environment (Kalkan and Zekioğlu, 2017). Getting stressed in races or training is an outgrowth. The bottom line for the athletes is to manage the stress and act so as not to mess himself, competitor or teammates over. Avoiding this behavior to reach aggression level is a significant necessity.

Aggression is just one of the reactions arising from situations such as failure or avoiding the behaviors toward the goal. Aggression is defined as the attitude exhibited as physical, verbal and symbolic to mess competitor over, block or militate against the competitor. This attitude is rooted in anger, fear, hostility, struggle and being precluded. Aggression in sports is described as the one or several of athlete, trainer or watchers who act in contemplation of damage someone by the effect of psychological, biological or environmental factors during a sportive competition (Işık et al., 2017).

Literature has several studies about sports satisfaction, stress levels (Eskin et al, 2013; Yücel et al, 2015; Şen, 2015; Afacan et al., 2017; Eraslan et al, 2017) and aggression levels (Gülcen, 2010; Bacioğlu and Özdemir, 2012; Kahraman and Kurt, 2013; Park et al., 2017; Khodayari et al., 2015) in different subject groups (Özdevecioğlu and Yalçın, 2010; Özmutlu, 2011), different sports branches (Öztürk et al, 2013; Afyon and Metin, 2014; Şerare, 2015; Şirin et al, 2016; Özdemir ve Abakay, 2017; Işık et al, 2017; Kırtepe et al, 2017; Kalkan and Zekioğlu, 2017) and again different age groups (Önen, 2009; Çelik and Otrar, 2009; Türksoy and Şarkıcı, 2003-11; Koçak, 2014; Uluışık and Pepe, 2015; Çelik et al, 2017). It is seen when the studies conducted evaluated that sports are both beneficial and important in the development of physiological, psychological and social feelings. Furthermore, it is mentioned that sports help individuals to control their aggression, stress and violence impulses and also teaches them to display positive behaviors.

Since standing in competitor's way comes into question in some of the branches by the nature of sports, there certainly are interventions toward the competitor in line with the rules of the branch. This circumstance unavoidably may cause to increase the aggression feeling of the athlete. Stress level increases because of the desire of winning the race; any athlete may display positive or negative behaviors in line with his/her feelings to take pleasure from achieving the goals. Two branches with different qualifications (contact and contactless) were selected to determine the effect of sports satisfaction on the stress and aggression level. It was aimed to make an investigation about the effect of sports satisfaction on stress and aggression level by considering the situation in which the competitor needs to be avoided and also the situation in which there is no contact with the competitor.

\section{Method}

\subsection{Research Group}

Research group consisted of the elite level and licensed athletes in Judo (39 people) and Swimming (21 people) branches within Kocaeli Metropolitan Municipality Sports Club. 60 athletes who are in 18-26 age range volunteered for the research.

\subsection{Data Collection Tools}

Three different scales as sports satisfaction scale, stress scale, and aggression scale were used in this survey to collect the data. Sports satisfaction scale consists of 56 expressions that are prepared based on Five Point Likert Scale (I am not satisfied at all=1, I am not satisfied=2, Neutral=3, I am satisfied=4, I am so satisfied=5) that was developed by Chelladurai and Riemer (1998). Stress scale is a scale that was used by Odabaşı (2006) for thesis called 'Stress in work 
life'. This scale that determines the stress level is prepared based on Five Point Likert Scale (never=1, seldom=2, occasionally $=3$, frequently $=4$, too often=5). Aggression level was determined by the aggression scale that was developed by Buss ve Perry (1992) and consists of 34 expressions. These expressions are prepared based on Five Point Likert Scale (It never fits=1, If fits too little=2, It fits a bit=3, It pretty fits=4, It completely fits=5) as well.

\subsection{Analysis of the Data}

After the data obtained was transferred to SPSS 24,00 packaged software, descriptive statistical results (average, standard deviation, frequency, and percentage) were computed and their conformity was tested to the normal distribution. Parametric tests were applied after determining that they show normal distribution. Analyses were conducted via Independent Simples t-test, One Way ANOVA, Pearson Correlation, and simple regression tests.

\section{Results}

Table 1. Frequency and percentage distributions belong to the parameters of the age range, gender, educational background, sports experience and the gender of trainer based on the branch variable.

\begin{tabular}{|c|c|c|c|c|}
\hline Branch & & & $\mathrm{F}$ & $\%$ \\
\hline \multirow{3}{*}{ Judo } & \multirow{6}{*}{ Age group } & 18-21 age & 22 & 56,4 \\
\hline & & $22-25$ ages & 7 & 17,9 \\
\hline & & Above 26 ages & 10 & 25,6 \\
\hline \multirow{3}{*}{ Swimming } & & 18-21 age & 10 & 47,6 \\
\hline & & $22-25$ ages & 8 & 38,1 \\
\hline & & Above 26 ages & 3 & 14,3 \\
\hline \multirow{2}{*}{ Judo } & \multirow{4}{*}{ Gender } & Male & 22 & 56,4 \\
\hline & & Female & 17 & 43,6 \\
\hline \multirow{2}{*}{ Swimming } & & Male & 9 & 42,9 \\
\hline & & Female & 12 & 57,1 \\
\hline \multirow{2}{*}{ Judo } & \multirow{4}{*}{ Educational background } & High school & 23 & 59,0 \\
\hline & & University & 16 & 41,0 \\
\hline \multirow{2}{*}{ Swimming } & & High school & 6 & 28,6 \\
\hline & & University & 15 & 71,4 \\
\hline
\end{tabular}

Entirely 60 athletes ( 31 males and 29 females) attended to the research. 39 of the participants do judo and 21 of them swim. 39 of the attendees are university graduates and 21 of them received training at high school level. Maximum participation was actualized in 18-21 age range (32 people). 
Table 2. Average and standard deviation values of stress, aggression and satisfaction scores based on branch variable

\begin{tabular}{|c|c|c|c|c|c|c|c|}
\hline & & & $\mathrm{N}$ & Min & $\operatorname{Max}$ & Mean & $\mathrm{Sd}$ \\
\hline \multirow{6}{*}{ 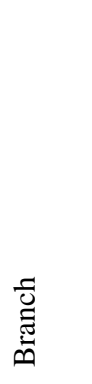 } & \multirow{3}{*}{ Judo } & Sports Satisfaction & 39 & 2,77 & 4,73 & 3,91 & 0,52 \\
\hline & & Stress & 39 & 1,00 & 3,60 & 2,77 & 0,55 \\
\hline & & Aggression & 39 & 1,74 & 4,26 & 2,60 & 0,50 \\
\hline & \multirow{3}{*}{ Swimming } & Sports Satisfaction & 21 & 2,61 & 4,73 & 3,72 & 0,58 \\
\hline & & Stress & 21 & 1,40 & 3,70 & 2,83 & 0,53 \\
\hline & & Aggression & 21 & 1,97 & 3,24 & 2,62 & 0,38 \\
\hline \multirow{6}{*}{$\begin{array}{l}\frac{\overline{0}}{0} \\
\overline{0}\end{array}$} & \multirow{3}{*}{ Male } & Sports Satisfaction & 31 & 2,77 & 4,50 & 3,78 & 0,47 \\
\hline & & Stress & 31 & 1,00 & 3,60 & 2,73 & 0,56 \\
\hline & & Aggression & 31 & 1,74 & 4,26 & 2,57 & 0,52 \\
\hline & \multirow{3}{*}{ Female } & Sports Satisfaction & 29 & 2,61 & 4,73 & 3,91 & 0,62 \\
\hline & & Stress & 29 & 2,10 & 3,70 & 2,86 & 0,51 \\
\hline & & Aggression & 29 & 1,85 & 3,24 & 2,64 & 0,40 \\
\hline \multirow{9}{*}{ 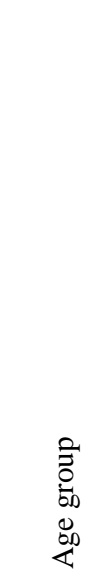 } & \multirow{3}{*}{ 18-21 ages } & Sports Satisfaction & 32 & 2,61 & 4,73 & 3,79 & 0,58 \\
\hline & & Stress & 32 & 1,00 & 3,60 & 2,88 & 0,57 \\
\hline & & Aggression & 32 & 1,85 & 4,26 & 2,72 & 0,45 \\
\hline & \multirow{3}{*}{ 22-25 ages } & Sports Satisfaction & 15 & 3,11 & 4,73 & 3,94 & 0,54 \\
\hline & & Stress & 15 & 2,00 & 3,70 & 2,68 & 0,53 \\
\hline & & Aggression & 15 & 2,00 & 3,32 & 2,67 & 0,43 \\
\hline & \multirow{3}{*}{$\begin{array}{l}\text { Above } \\
\text { ages }\end{array}$} & Sports Satisfaction & 13 & 3,02 & 4,43 & 3,85 & 0,46 \\
\hline & & Stress & 13 & 1,40 & 3,20 & 2,70 & 0,44 \\
\hline & & Aggression & 13 & 1,74 & 2,88 & 2,25 & 0,37 \\
\hline \multirow{6}{*}{ 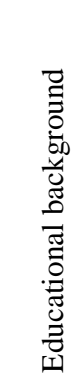 } & \multirow{3}{*}{ High school } & Sports Satisfaction & 29 & 2,91 & 4,73 & 3,94 & 0,51 \\
\hline & & Stress & 29 & 2,10 & 3,60 & 2,81 & 0,49 \\
\hline & & Aggression & 29 & 1,85 & 4,26 & 2,63 & 0,48 \\
\hline & \multirow{3}{*}{ University } & Sports Satisfaction & 31 & 2,61 & 4,73 & 3,75 & 0,57 \\
\hline & & Stress & 31 & 1,00 & 3,70 & 2,78 & 0,59 \\
\hline & & Aggression & 31 & 1,74 & 3,32 & 2,58 & 0,45 \\
\hline
\end{tabular}

It is seen when sports satisfaction, stress and aggression levels are evaluated in terms of the branch, gender, age group and educational background variables that the averages of sports satisfaction are high. 
Table 3. Values belong to the differences between stress, aggression and aggression levels based on the branch, gender and education variables.

\begin{tabular}{|c|c|c|c|c|c|c|c|}
\hline & & & $\mathrm{N}$ & Mean & $\mathrm{Sd}$ & $\mathrm{t}$ & $\mathrm{p}$ \\
\hline \multirow{6}{*}{ Branch } & \multirow[t]{2}{*}{ Sports satisfaction } & Judo & 39 & 3,91 & 0,52 & \multirow{2}{*}{1,228} & \multirow{2}{*}{0,22} \\
\hline & & Swimming & 21 & 3,72 & 0,58 & & \\
\hline & \multirow[t]{2}{*}{ Stress } & Judo & 39 & 2,77 & 0,55 & \multirow{2}{*}{,- 365} & \multirow{2}{*}{0,71} \\
\hline & & Swimming & 21 & 2,83 & 0,53 & & \\
\hline & \multirow[t]{2}{*}{ Aggression } & Judo & 39 & 2,60 & 0,50 & \multirow{2}{*}{,- 207} & \multirow{2}{*}{0,83} \\
\hline & & Swimming & 21 & 2,62 & 0,38 & & \\
\hline \multirow{6}{*}{ Gender } & \multirow[t]{2}{*}{ Sports satisfaction } & Male & 31 & 3,78 & 0,47 & \multirow{2}{*}{,- 854} & \multirow{2}{*}{0,39} \\
\hline & & Female & 29 & 3,91 & 0,62 & & \\
\hline & \multirow[t]{2}{*}{ Stress } & Male & 31 & 2,73 & 0,56 & \multirow{2}{*}{,- 931} & \multirow{2}{*}{0,35} \\
\hline & & Female & 29 & 2,86 & 0,51 & & \\
\hline & \multirow[t]{2}{*}{ Aggression } & Male & 31 & 2,57 & 0,52 & \multirow{2}{*}{,- 547} & \multirow{2}{*}{0,58} \\
\hline & & Female & 29 & 2,64 & 0,40 & & \\
\hline \multirow{6}{*}{ Education } & \multirow[t]{2}{*}{ Sports satisfaction } & High school & 29 & 3,94 & 0,51 & \multirow{2}{*}{1,382} & \multirow{2}{*}{0,17} \\
\hline & & University & 31 & 3,75 & 0,57 & & \\
\hline & \multirow[t]{2}{*}{ Stress } & High school & 29 & 2,81 & 0,49 & \multirow{2}{*}{, 165} & \multirow{2}{*}{0,87} \\
\hline & & University & 31 & 2,78 & 0,59 & & \\
\hline & \multirow[t]{2}{*}{ Aggression } & High school & 29 & 2,63 & 0,48 & \multirow{2}{*}{, 434} & \multirow{2}{*}{0,66} \\
\hline & & University & 31 & 2,58 & 0,45 & & \\
\hline
\end{tabular}

There are no statistically significant differences $(p>0,05)$ based on branch, gender and education statuses in stress, aggression and satisfaction levels.

Table 4. Values belong to differences between stress, aggression and satisfaction levels based on age groups variable

\begin{tabular}{|c|c|c|c|c|c|c|c|}
\hline & & Sum of Squares & df & Mean Square & $\mathrm{F}$ & Sig. & Post Hoc \\
\hline \multirow{3}{*}{ Sports satisfaction } & Between Groups &, 224 & 2 &, 112 & \multirow{3}{*}{, 363} & \multirow{3}{*}{0,697} & \\
\hline & Within Groups & 17,615 & 57 & ,309 & & & \\
\hline & Total & 17,839 & 59 & & & & \\
\hline \multirow{3}{*}{ Stress } & Between Groups &, 548 & 2 & ,274 & \multirow{3}{*}{,932 } & \multirow{3}{*}{0,400} & \\
\hline & Within Groups & 16,762 & 57 &, 294 & & & \\
\hline & Total & 17,310 & 59 & & & & \\
\hline \multirow{3}{*}{ Aggression } & Between Groups & 2,182 & 2 & 1,091 & \multirow{3}{*}{5,839} & \multirow{3}{*}{$0,005 *$} & \multirow{3}{*}{$3 / 1,2$} \\
\hline & Within Groups & 10,653 & 57 & , 187 & & & \\
\hline & Total & 12,835 & 59 & & & & \\
\hline
\end{tabular}

${ }^{*} \mathrm{p}<0,01$ 
There are significant differences $(\mathrm{p}<0,01)$ between stress, aggression and sports satisfaction levels based on age groups. These differences are between 26 ages and elder $(2,25 \pm 0,37)$ athletes, the athletes in 18-21 age group $(2,72 \pm 0,45)$ and the athletes in $22-25$ age group $(2,67 \pm 0,43)$

Table 5. Relationship between the levels of stress, aggression, satisfaction and the branches and age groups of the athletes

\begin{tabular}{|c|c|c|c|c|c|c|c|}
\hline & & Age & Branch & $\begin{array}{l}\text { Educational } \\
\text { background }\end{array}$ & $\begin{array}{l}\text { Sports } \\
\text { satisfaction }\end{array}$ & Stress & Aggression \\
\hline \multirow{2}{*}{ Branch } & $\mathrm{r}$ &,- 015 & 1 & & & & \\
\hline & $\mathrm{p}$ & ,908 & & & & & \\
\hline \multirow{2}{*}{$\begin{array}{l}\text { Educational } \\
\text { background }\end{array}$} & $\mathrm{r}$ &, $406^{* *}$ &, $290^{*}$ & 1 & & & \\
\hline & $\mathrm{p}$ & 0,001 &, 025 & & & & \\
\hline \multirow{2}{*}{ Sports satisfaction } & $\mathrm{r}$ &, 064 &,- 159 &,- 178 & 1 & & \\
\hline & $\mathrm{p}$ & ,628 &, 224 &, 174 & & & \\
\hline \multirow{2}{*}{ Stress } & $\mathrm{r}$ &,- 155 & ,048 &,- 022 &,$- 320^{*}$ & 1 & \\
\hline & $\mathrm{p}$ & ,236 &, 717 &, 870 & 0,013 & & \\
\hline \multirow{2}{*}{ Aggression } & $\mathrm{r}$ &,$- 374^{* *}$ & 027 &,- 057 &,- 063 & 230 & 1 \\
\hline & $\mathrm{p}$ & $\mathbf{0 , 0 0 3}$ & ,837 & ,666 & ,634 & ,078 & \\
\hline
\end{tabular}

$* * \mathrm{p}<0,01 / * \mathrm{p}<0,05$

As is seen in Table, there is a negative and significant relationship between sports satisfaction and stress $(r=-, 320$; $\mathrm{p}<0,05)$. As the sports satisfaction increases, the stress decreases at the same time. There is seen a negative and insignificant relationship between sports satisfaction and aggression $(r=-, 063 ; p>0,05)$. A negative and significant relationship between age group and aggression levels can be observed $(r=-, 374 ; p<0,01)$. As the age decreases, the aggression level increases at the same time.

Table 6. Simple regression analysis table relating to the effect of sports satisfaction on the stress level of the athletes

\begin{tabular}{c|l|l|l|l|l|l|l|l}
\hline $\mathrm{B}$ & $\mathrm{SE}$ & $\beta$ & $\mathrm{t}$ & $\mathrm{p}$ & $\mathrm{R}$ & $\mathrm{R}^{2}$ & $\mathrm{~A} \mathrm{R}^{2}$ & $\mathrm{~F}$ \\
\hline$\tilde{\omega} \cong-, 315$ &, 123 &,- 320 & $-2,575$ & $\mathbf{0 , 0 1 3} *$ &, 320 &, 103 &, 087 & 6,629 \\
\hline
\end{tabular}

$* \mathrm{p}<0,05$ Dependent Variable: Stress

Explanation ratio of sports satisfaction for the stress level is $8 \%$. The effect of sports satisfaction on the stress is negatively directed and $32 \%$. As the sports satisfaction increases, the stress level of the athletes decreases.

Table 7. Simple regression analysis table relating to the effect of sports satisfaction on the aggression level of the athletes

\begin{tabular}{cc|l|l|l|l|l|l|l|l}
\hline \multicolumn{2}{c|}{ B } & SE & $\beta$ & $\mathrm{t}$ & $\mathrm{p}$ & $\mathrm{R}$ & $\mathrm{R}^{2}$ & $\mathrm{~A} \mathrm{R}^{2}$ & $\mathrm{~F}$ \\
\hline Sports Satisfaction &,- 053 &, 111 &,- 063 &,- 478 & 0,634 &, 063 &, 004 &,- 013 &, 229 \\
\hline
\end{tabular}

$\mathrm{p}>0,05$ Dependent Variable: Aggression

There is a negative and insignificant relationship between the sports satisfaction and aggression levels ( $\mathrm{R}=-, 069$, $\left.\mathrm{R}^{2}=, 004, \mathrm{~F}=, 229, \mathrm{p}>0,05\right)$ 
Table 8. Simple regression analysis table relating to the effect of age groups on the aggression level

\begin{tabular}{ll|l|l|l|l|l|l|l|l}
\hline & B & SE & $\beta$ & $\mathrm{t}$ & $\mathrm{p}$ & $\mathrm{R}$ & $\mathrm{R}^{2}$ & $\mathrm{~A} \mathrm{R}^{2}$ & $\mathrm{~F}$ \\
\hline Ages &,- 215 &, 070 &,- 374 & $-3,076$ &, 003 &, 374 &, 140 &, 125 & 9,460 \\
\hline
\end{tabular}

Dependent Variable: Agression

Explanation ratio of the age group for aggression levels is $12,5 \%$. The effect of the age group on aggression is negatively directed and $37,4 \%$. As the age decreases, the aggression levels of the athletes increase at the same time.

\section{Discussion}

There was not found any statistically significant difference based on the branches in this research that was conducted to determine the effect of sports satisfaction on the stress and aggression in judoka and swimmers. With reference to the literature, the people who deal with individual sports have aggression tendency at a lower level in comparison with the people who have interest in the team sport. The results match up with each other in terms of the sports branches selected are the individual sports. Işık et. al. (2017) mentioned that aggression level averages of persons having impaired hearing are under the medium-level. These results support our survey as well. However, according to Tutkun et al. (2010), being higher the aggression levels of athletes who deal with individual sports than the aggression levels of athletes who have an interest in team sports is an expected result because of the characteristics of the sports branch. The results that do not match up with the results of Tekin et. al., (2011) when we classified the branches as contact and contactless. They pointed out that the general aggression levels are higher in sports branches necessitate contact. However, the average scores of aggression were found as lower in this study.

Ulusşı and Pepe (2015) evaluated stress levels based on the sports type and found that the stress level of athletes who play individual sports are higher than the stress level of athletes who play team sports. The success completely hinges upon the individual skills of the athletes. This is because the stress level of the students who play individual sports is higher in comparison with the students have interest in team sports. In this research, evaluations can be seen on the basis of individual sports; with reference to the findings, the stress level of athletes is not high. When we consider that there are several factors affect the stress level, the studies about different parameters should be performed by increasing the variety of sports branches to get further and comprehensive information

There was not found any statistically significant difference based on educational background variable. Özdemir and Abakay (2017) found that the points of communication and aggression sub-dimensions do not vary in terms of the educational background. However, these investigators pointed out that as the educational background decreases, destructive and passive aggression scores increase in female volleyball players.

There was not found any statistical differences when the sports satisfaction, stress and aggression level were compared based on the gender variable. However, the average points of females are higher than the average points of males. According to Bebetsos (2015), there is no difference between gender variable and sports satisfaction (Şirin et al., 2016). Also, Kirtepe et al., (2017) did not find differences between the satisfaction levels based on the gender. Another survey that confirms our research results is the study of Eraslan et al., (2017). They mentioned that the female participants have higher point averages about overcoming the stress. With reference to Çelik et al. (2017), aggression level of female participants is higher than the aggression level of male participants. Przybycien et al. (2017) found significant differences between the stress and aggression levels based on the gender variable. They also mentioned that stress and aggression scores of females are lower in comparison with the scores of males.

There are statistically significant differences $(\mathrm{p}<0,01)$ between stress, aggression and sports satisfaction levels based on the age groups; these differences are between 26 years and elder ones $(2,25 \pm 0,37), 18-21$ years $(2,72 \pm 0,45)$ and $22-25$ years $(2,67 \pm 0,43)$ in aggression dimension. Dalkılıç et al. (2013) conducted a study and determined that the aggressive tendencies of the athletes between 15and 19 ages are higher than the aggressive tendencies of the athletes who are 20 years and elder. Their survey shares similarity with ours. Following studies show similarity with our survey as well. Şen (2015) found significant differences in stress levels of male students who professionally play football and amateurishly play football based on the age variable. Besides, Korkmaz et al. (2009) performed a study called 'Satisfaction levels of table tennis players of Turkey Super League'. They found a significant difference in satisfaction levels of athletes based on the age variable (Şirin et al., 2016). It is possible to talk about opposite results as well. For instance, Afyon and Metin (2015) found difference in aggression levels of athletes based on the age groups. Kurtepe et al., (2017) did not find differences in Athlete Satisfaction Levels of Athletes who participate in Turkey Intervarsity Handball Competitions based on the age variable. Also, Türksoy (2007) did not specify any significant difference based on the age variable in his study that is about the football players (Kirtepe et al., 2017). It is seen there is no significant difference between the 
age and athlete satisfaction in a study about the wrestlers (Şirin et al., 2016). According to Kaya et al. (2010), there are significant differences in stress levels of athletes in 13-15 age groups.

As we mentioned before, negative relationships are determined by the sports satisfaction, stress and aggression. The explanation ratio of sports satisfaction for the stress of athletes is $8 \%$. The effect of sports satisfaction on the stress is negatively directed and $32 \%$. In other words, as the sports satisfaction increases, the stress level decreases at the same time. There is the negative relationship between sports satisfaction and aggression levels. Moreover, there is a positive but insignificant connection between the stress and aggression levels. Variety of sports branches should be increased and evaluations ought to be made in line with the sub-dimensions in the scales to reach further data within this scope. Because there will occur differences in stress, aggression or satisfaction levels based on the individual characteristics of the athletes and the original principles of each of the sports branches. Therefore, diversifying the sports branches and comparing the athletes in terms of different variables become more of an issue.

The explanation ratio of the age group for the aggression levels of athletes is $12,5 \%$ when the relationship between sports satisfaction, stress and aggression levels is evaluated based on the age groups. The effect of age group on the aggression is negative and 37,4\%. As the age decreases, aggression levels of athletes increase. Işık et al. (2017) found that as the ages of persons having impaired hearing, their aggression levels decrease. With reference to their comment, as the age increases, coping skills increase as well. Bacıŏlu and Özdemir (2012) found positive and significant relationships between the age variable and total aggression scores; as the age of students increases, their aggressive behaviors increase at the same time.

Emire and Şanal (2011) found a positive relationship between aggression and age variables; however, they could not determine a significant correlation between the stress level and age variable. In this research, there is found a positive relationship between age and aggression; a negative and insignificant relationship between the stress level and age variable. Eraslan et al. (2017) mentioned that as the age level increases, there occurs a decrease in the scores of overcoming the stress. The reason for this circumstance may be the fear of losing and being exposed to the similar applications by the increase in age levels.

As the age progresses, the experience of the athletes increases. They can minimize the stress by their experiences and evaluation skills for these experiences. This minimization may decrease the aggressive behaviors. However, there is the need for more studies to reach the proved data about this assumption. Because, not only the experience of athlete but also the level of the relationship with the trainer, watcher, etc., may affect the stress, aggression and satisfaction level of the athlete. Therefore, the studies that will be conducted in terms of the variables mentioned can provide investigators to reach reliable data.

\section{References}

Afacan, E., Onağ, Z., Demiran, D., \& Çobanoğlu, G. (2017). The Reasons for Violence in Football and the Ways to Prevent Them According To Professional Football Players Views: The Match Between Tarsus İdman Yurdu Erkutspor and Yeni Salihlispor. International Journal of Social Science Research, 6(2), 124-141.

Afyon, Y. A., \& Metin, S. C. (2015). The Examine of the Aggressiveness Level of Super Amateur Football Players in Mugla. Journal of Sports and Performance Researches. 6(1), 5-11.

Bali, A. (2015). Psychological Factors Affecting Sports Performance. International Journal of Physical Education, Sports, and Health. 1(6): 92-95

Çelik, A., Zengin, S., \& Baş, M. (2017). Determining the Level of Aggression in Athletes High School Students. Journal of Gaziantep University Sports Sciences 2(4), 20-31.

Çelik, H., \& Otrar, M. (2009). The Adaptation of Aggression Inventory into Turkish: Validity and Reliability Studies. M.Ü. Atatürk Education Faculty and Journal of Educational Sciences. 29, 101-120.

Dalkılıç M., Mamak H., Ramazanoglu, F., Kumartaslı, M., Akdagcık, I. U., \& Cenikli, A. (2013). The Analysis of the Aggression Oriented Tendencies of the Sportsmen Active in Different Sports Branches. Journal of Education and Sociology, 4(2), 109-113. https://doi.org/10.7813/jes.2013/4-2/16

Demir, H., Altın, M., Demirel, H., Buğdaycı, S., \& Yalçın, Y. G. (2017). The Styles of Coping with Stress among the Students Studying At the Schools Which Admit the Students with a Special Talent Exam. 3(8), 108-119.

Donat, B. S., \& Özdemir, Y. (2012). Relationships Between Age, Gender, Success Status, Anger And Aggression Behaviors Of Primary School Students. Journal of Educational Sciences Research. 2(2), 169-187.

Emire, Ö. K., \& Şanal, M. (2011). The Investigation of Stress and Aggression Levels in Hearing-Impaired Sportsmen Aged Between 18-25 Years Old. Science, Movement, and Health. 11(2), 166-171. 
Eraslan, M., Karafil, A. Y., \& Atay, E. (2017). Evaluation Of Strategies For Managing Stress Among Muay Thai Sportsmen Participating İn İntervarsity Sports Competitions. Journal of Human Sciences, 14(3), 2915-2924. https://doi.org/10.14687/jhs.v14i3.4591

Eskin, M., Harlak, H., Demirkıran, F., \& Dereboy, Ç. (2013). The Adaptation of the Perceived Stress Scale into Turkish: A Reliability and Validity Analysis. New/Yeni Symposium Journal. 51(3), 132-140.

Göksel, A. G., Caz, Ç., Yazıcı, Ö. F., \& İkizler, H. C. (2017). Comparison of Attitudes of Students from Different Departments towards Sport: The Model of Marmara University. 8(2), 123-134.

Gözün, K. Ö., \& Kurt, G. (2013). Examination of the Prosocial and Aggressive Tendencies of Preservice Teachers. Journal of Higher Education and Science. 3(3), 236-243.

Gülcen, B. (2010). Sexual Dimorphism In Craniofacial Dimensions In Young Adults Related With Aggressive Behavior. Başkent University Medical Faculty, Department Of Anatomy, Dissertation. Ankara.

Işık, M., Kılıç, İ., \& Aksoy, K. (2017). Aggression Levels of Hearing Impaired Athletes: A Comparison of Individual and Team Sports. Journal of Human Sciences, 14(4), 3221-3229. https://doi.org/10.14687/jhs.v14i4.4832

Kalkan, N., \& Zekioğlu, A. (2017). Evaluation of Psychological Factors Affecting Performance of Fencing Players According To Fencing Coaches: Qualitative Study. Journal of National Sports Sciences, 1(1), 29-42.

Kaya, M., Yardımcı, M., Sarıtaş, N., Kaya, E. Ö., \& Pepe, O. (2010). The Comparison of Stress and Burnout Levels of 13-15 Aged Sportsmen Blinds. Science, Movement, and Health. 10(2), 163-165.

Khodayari, A., Hadavi, F., \& Mohammadi, M. J. B. (2015). The Relationship Between Communication Skills With Aggression And Perfectionism Of Lifeguards. Annals of Applied Sports Science. 3(3), 35-42. https://doi.org/10.18869/acadpub.aassjournal.3.3.35

Kırtepe, A., Altungül, O., \& Karahüseyinoğlu, M. F. (2017). Determination of the Satisfaction Levels of Athletes Who Participated In Universities Turkey Handball Championship. The Journal of Academic Social Science, 5(51), 404-411. https://doi.org/10.16992/ASOS.12525

Koçak, F. (2014). Undergraduate Students' Attitudes towards Sport: A Scale Development Study. Ankara University, Faculty of Sports Sciences. 12(1), 59-69.

Önen, E. (2009). Investigation the Psychometric Properties of Aggression Questionnaire for Turkish Adolescents." Journal of Turkish Psychological Advice and Guidance 2009, 4(32), 75-84.

Örücü, E., Kılıç, R., \& Ergül, A. (2011). The Effects of Stress on Individual Performance in Business Life: A Research for Education and Healthcare Staff. Journal of Academic View. 26, 1-21.

Özdemir, N., \& Abakay, U. (2017). Investigation of Aggression Level and Communication Skills of Female Volleyball and Football Players. Journal of Gaziantep University Sports Sciences. 2(1), 41-52.

Özdevecioğlu, M, \& Yalçın, Y. (2010). The Effect of Sports Satisfaction on Stress and Aggression Levels in Sportsman. Niğde University Journal of Physical Education and Sports Sciences. 4(1), 63-76.

Özmutlu, İ. (2011). The Relevance of Servant Leadership Behaviors to Athlete Satisfaction in Physically Handicapped Athletes.Gazi University, Health Sciences Institute, Department Of Physical Education And Sports, Doctoral Thesis. Ankara.

Park, S, Chiu, W., \& Won, D. (2017). Effects of Physical Education, Extracurricular Sports Activities and Leisure Satisfaction on Adolescent Aggressive Behavior: A Latent Growth Modeling Approach. Plos One. 12(4):E0174674. https://doi.org/10.1371/journal.pone.0174674

Şen, G. (2015). The Comparison Of The Depression, Anxiety And Stress Levels Of Male Students Between The Ages Of 13-18 Who Play Football Professionally And Don't. Istanbul Arel University, Social Sciences Institute, Department Of Psychology, Master's Thesis. İstanbul.

Şerare, S. (2015). The Relationship Between Educational Background And Aggression In Male Team Athletes. 8th National Sports Science Student Congress (14-16 May 2015, Mersin University (School Of Physical Education and Sports). 113-115.

Şirin, Y., Bilir, P., Öz, G., \& Sangun, L. (2016). Determination of the Satisfaction Levels of Athletes Who Participated In Intercollege Turkish Wrestling Championship In Terms Of Their Demographic Features. Journal of Sports and Performance Researches. 7(2), 113-119.

Sterkowicz-Przybycien, K., Blecharz, J., \& Sterkowicz, S. (2017). Motivation in Judo: Rethinking the Changes in the European Society. Arch Budo-Science of Material Arts. 13, 227234. 
Tekin, A., \& Eliöz, M. (2011). The Investigation of Kick-Boxers' Anger and Aggression Levels by Various Variables. Journal of Sports Sciences of Turkey Kickboxing Federation, 4(1), 34-48.

Türksoy, A., \& Sarkıc1, T. (2003-11). 12-14 Age Range Football Players Satisfaction on the Perceived and Preferred With the Leader Behaviors of Their Coaches. İ.Ü. Journal of Sports Sciences. (Sv) 200-203.

Türksoy, A., Öztürk, M., Ataman Yanc1, H. B., \& Karalınoğlu, D. (2013). Leadership and Satisfaction of the Turkish Young National Football Team Players. Ilb International Refereed Academic Social Sciences Journal. 4(10)110-119.

Tutkun, E., Güner, B. Ç., Ağaoğlu, S. A., \& Soslu, R. (2010). Assessment Of Aggression Levels Of Athletes Who Play Team Sports And Individual Sports. Journal of Sports and Performance Research, 1(1), 23-29.

Uluışı, V., \& Pepe, K. (2015). Investigations of Stress and Aggression Level of High School Students In Terms Of Some Variables. Journal of International Sports Sciences. 1(1), 1-13.

Yücel, A. S., Atalay, A., \& Gürkan, A. (2015). Factors Affecting Violence And Aggression In Sports. International Journal of Psychiatry and Psychological Researches. 2(2), 68-90. https://doi.org/10.17360/UHPPD.201529603

\section{Copyrights}

Copyright for this article is retained by the author(s), with first publication rights granted to the journal.

This is an open-access article distributed under the terms and conditions of the Creative Commons Attribution license which permits unrestricted use, distribution, and reproduction in any medium, provided the original work is properly cited. 